\title{
African science and global opinions
}

In late 2021, African scientists discovered a new variant of COVID-19. We should be proud and grateful, as should and is the world, to our scientists for identifying the latest variant of COVID and for choosing, correctly, to communicate this scientific information rapidly. But this important discovery led to global action not based on science. Wealthier countries closed their doors to our country and continent, implementing a travel ban. This reaction was despite the views of scientists in South Africa and recommendations from the World Health Organization. Since then, there have been other travel bans, other mistakes globally in managing the global pandemic.

This travel ban, despite evidence of spread of the Omicron variant in countries which selectively closed their borders, had potentially devastating implications for health and well-being on our continent. African scientists were exemplary in continuing to explore and report on the variant. The travel ban, which was not evidence- or science-based, has correctly been described by a group of eminent African scientists as 'political theatre'1, and the health consequences for Africans, as these authors pointed out, had the potential to be grave, given the economic implications of travel bans. The irony of this is clear: as Africa helped in all likelihood to make the world more healthy, many in the world have helped to make Africans more sick.

What does this mean for South African and African science? Perhaps the saddest (and most obvious) observation is that the kind of reaction we saw is nothing new. We witnessed the reinscription - with potentially grave economic, personal, and health consequences - of dangerous assumptions about Africa, contagion, dirt and pollution. As our country and continent led the world in science and science communication, we again bore the brunt of the long and ongoing tail of dangerous, colonial, and non-evidence-based views. The view of Africa as a source, not of knowledge, but of pestilence and shame was a feature of much writing about our continent by social scientists and others going back centuries. Despite clear evidence of the contributions of Africa and Africans to science and knowledge ${ }^{2-4}$, Africa was once again being viewed strongly through the lens of pathology.

In South Africa, much of the focus in issues of transformation of the sciences, especially in the post-\#FeesMustFall era, has been on inequality in South Africa itself, and questions of access for people formerly excluded from higher education. ${ }^{5-8}$ This is appropriate and necessary, and theorists have been careful to link current issues to colonial and apartheid history. The contradictions around the early identification of the Omicron variant, however, refocus our attention on ongoing global politics and its influence on contemporary scientific practice and perceptions of science. A key feature of how African science continues to be viewed is through the lens of 'capacity building'. There is nothing wrong with capacity building, and it is very often to be welcomed; but all too easily, talk about 'building capacity' reinforces stereotypes about inferior quality African science, and dependency of African scientists on the greater expertise of those in the Global North.., 10 This is despite the fact that African scientists lead the world in a number of areas including HIV/Aids and ecology/conservation biology, to name just two fields. ${ }^{11,12}$ It is crucial for South African science that unhelpful and inaccurate stereotypes be questioned and resisted, and that evidence is brought to bear in all discussions about what African science is and does. Unfortunately, the Omicron variant scandal shows once again how powerful stereotypes may outweigh the facts.

The South African Journal of Science shares with our contributors and our readership a responsibility to insist on evidence-based opinion and argument, to face difficulties and gaps where they do occur, and to attempt to rectify these, but also to question and rebut incorrect stereotypes. Within the field of studies related to COVID-19, for example, we are planning later this year to publish a special issue on the topic, with the subheading 'How to do social distancing in a shack?' This focus on interdisciplinary work which takes due account of the conditions under which most people in the world live is not, we suggest, an add-on to global science. We hope that the special issue will show that considering context, placing science within the realities of the majority world, and understanding the global politics of inequality and exclusion, is at the cutting edge of good science. If we are to be decolonial in our scientific practices, we must always be clear on what the shortcomings are of what we do, but we must also be clear that Africa, and African science, need to be evaluated on their own contextual merits. Political theatre ${ }^{1}$ is powerful, but it is not science or science policy.

\section{References}

1. Mendelson M, Venter F, Moshabela M, Gray G, Blumberg L, De Oliveira T, et al. The political theatre of the UK's travel ban on South Africa. Lancet. 2021;398:2211-2213. https://doi.org/10.1016/S0140-6736(21)02752-5

2. Beinart W, Dubow S. The scientific imagination in South Africa: 1700 to the present. Cambridge, UK: Cambridge University Press; 2021. https://doi. org/10.1017/9781108938198

3. Gevers W. A well-told history of science in South Africa. S Afr J Sci. 2021;117(9/10), Art. \#11967. https://doi.org/10.17159/sajs.2021/11967

4. Ali W, Elbadawy A. Research output of the top 10 African countries : An analytical study. COLLNET J Sci Inf Manag. 2021;15(1):9-25. https://doi.org $/ 10.1080 / 09737766.2021 .1934181$

5. CMoloi K, Makgoba MW, Ogutu Miruka C. (De)constructing the \#FeesMustFall campaign in South African higher education. Contemp Educ Dialogue. 2017;14(2):211-223. https://doi.org/10.1177/0973184917716999

6. Tirivangasi HM, Rapanyane MB, Mugambiwa SS. The toxicity of welfare state: Discourse analysis of \#FeesMustFall movement in South Africa. Afr J Peace Conflict Stud (formerly Ubuntu J Conflict Soc Transform). 2021;10(2):7-29. https://hdl.handle.net/10520/ejc-aa_ubuntu1-v10-n2-a1

7. Costandius E, Nell I, Alexander N, Mckay M, Blackie M, Malgas R, et al \#FeesMustFall and decolonising the curriculum: Stellenbosch University students' and lecturers' reactions. S Afr J High Educ. 2018;32(2):65-85 https://doi.org/10.20853/32-2-2435

8. Lewis D, Hendricks CM. Epistemic ruptures in South African standpoint knowledge-making: Academic feminism and the \#FeesMustFall movement. Gender Questions. 2017;4(1):18. https://doi.org/10.25159/2412-8457/2920

9. Mormina M, Istratii R. 'Capacity for what? Capacity for whom?' A decolonial deconstruction of research capacity development practices in the Global South and a proposal for a value-centred approach [version 1; peer review: 2 approved]. Wellcome Open Res. 2021;6:129. https://doi.org/10.12688/ wellcomeopenres.16850.1

10. Swartz L. Building capacity or enforcing normalcy? Engaging with disability scholarship in Africa. Qual Res Psychol. 2018;15(1):116-130. https://doi.or $\mathrm{g} / 10.1080 / 14780887.2017 .1416801$

11. Hodes R, Morrell R. Incursions from the epicentre: Southern theory, social science, and the global HIV research domain. Afr J AIDS Res. 2018;17(1):22-31. https://doi.org/10.2989/16085906.2017.1377267

12. Asase A, Mzumara-Gawa TI, Owino JO, Peterson AT, Saupe E. Replacing "parachute science" with "global science" in ecology and conservation biology. Conserv Sci Pract. 2021; e517. https://doi.org/10.1111/csp2.517

HOW TO CITE:

Swartz L. African science and global opinions. S Afr J Sci. 2022;118(1/2), Art. \#13062. https://doi.org/10.17159/sajs.2022/13062 